\title{
Environmental and Geochemical Parameters of Bottom-Sediment from the Southern Bug Estuary
}

\author{
Olena Mitryasova ${ }^{1 *}$, Piotr Koszelnik ${ }^{2 *}$, Renata Gruca-Rokosz², \\ Victor Smyrnov ${ }^{1}$, Svitlana Smyrnova ${ }^{1}$ Małgorzata Kida², \\ Sabina Ziembowicz ${ }^{2}$, Yevhen Bezsonov' ${ }^{1}$, Andrii Mats ${ }^{3}$ \\ 1 Petro Mohyla Black Sea National University, 68 Desantnykiv, 10, Mykolaiv, 54003, Ukraine \\ 2 Rzeszow University of Technology, ul. Powstańców Warszawy 12, 35-959, Rzeszów, Poland \\ 3 Maria Curie-Skłodowska University, pl. M. Curie-Skłodowskiej 5, 20-031, Lublin, Poland \\ * Corresponding author's e-mail: pkoszel@prz.edu.pl
}

\begin{abstract}
The bottom sediments of river hydroecosystems were studied for the gross content of heavy metals $(\mathrm{K}$, Ti $\mathrm{Cr}$, $\mathrm{Fe}, \mathrm{Ni}, \mathrm{Cu}, \mathrm{Zn}, \mathrm{Rb}, \mathrm{Sr}$ and $\mathrm{Hg}$ ). The environmental and geochemical processes of bottom-sediment formation in aqua landscapes were analyzed, allowing us to stress the need to determine the methodological basis for the correlation-regression dependence of the heavy metal accumulation processes in bottom sediments, as well as total content of organic carbon. The ranking of pairwise correlation coefficients arranged in decreasing order is: TOC: $\mathrm{Cu}(0.87)>$ TOC:K (0.82)> TOC: Ni (0.75)> TOC: $\mathrm{Sr}(0.73)>\mathrm{TOC}: \mathrm{Fe},(0.7)>\mathrm{TOC}: \mathrm{Ti}(0.67)>\mathrm{TOC}: \mathrm{Hg}(0.63)>$ TOC: $\mathrm{Cr}(0.58)>\mathrm{TOC}: \mathrm{Rb}(0.56)>$ and TOC:Zn (0.51). The proposed methodological approach determines the environmental and geochemical aspects of the sedimentation processes heavy metals, while also identifying the general trends in hydroecosystems prone to the anthropogenic impact.
\end{abstract}

Keywords: heavy metals, hydroecosystem, bottom sediments, water resources.

\section{INTRODUCTION}

In recent decades, the negative consequences of human activities have been accepted as of large size, with global proportions and an international character. This is true in the case of the impact on the quality of surface waters, which has been further aggravated by climate change (Raneesh 2014; Miller et al. 2020; Mitryasova et al. 2017; Czarnota and Masłon 2020). In the context of this growing anthropogenic impact on water resources, the attempts to preserve the natural environment are crucial, as is the detailed study of all the different components of aquatic ecosystems, including the bottom sediments. Indeed, qualitative assessment of various aspects of aquatic ecosystems is a priority towards achieving the goals of sustainable development (Bezsonov et al. 2017; Martsenyuk et al. 2016; Mitryasova et al. 2016;
Petruk et al. 2016; Pohrebennyk et al. 2019; Styskal et al. 2016, Bartoszek et al. 2020). The study of bottom sediments in hydroecosystems is important, given such ongoing processes as the deposition, distribution and migration of pollutants are considered to threaten the functioning of the aquatic biota, as well as the human health. Out of the various pollutants involved, heavy metals are the ones highlighted here, in relation to the processes of transformation that affect them.

Our object of study was the Southern Bug, i.e. a river located in SW Ukraine that forms a hydroecosystem from an ecological point of view. Against such a background, bottom sediments can be regarded as constituting an independent biosynthetic body potentially metabolising material and energy in linkage with the wider natural environment. Bottom sediments are able to serve an indicative function vis-à-vis 
the intensity of anthropogenic loading, the lateral and radial distribution of pollution, and integral spatial structure.

The need to study the very extensive hydroecosystem of the Southern Bug arises out of specific geochemical features of the surrounding areas, given the intensity and nature of the local human economic activity. The problem of heavy metal accumulation can be seen as in direct proportion to that of the pollution of surface waters. This accounts for the aforementioned role of bottom sediments as indicators of the ecological state in which hydroecosystems find themselves. The research into the geochemical characteristics of sediments within a river basin is also a priority for those implementing the EU Water Framework Directive, which is based on regional-level water management on a basin-by-basin basis (Mitryasova et al. 2020).

It is important to focus on the toxicological features of heavy metals as priority pollutants of surface waters. A generally-accepted definition holds that as many as 40 elements in the periodic table of atomic mass above 50 AU may be thought of as heavy metals. Classification within a single group is further justified by the peculiarities of their physical and chemical activity within biosystems. These are conserved pollutants that do not decompose as they migrate through the trophic chains present in hydroecosystems. The list of dangerous traits associated with their deposition and accumulation within biota includes toxicity, mutagenicity and carcinogenicity.

In our opinion, it is quite careless to classify chemical elements into the heavy metal group in line with the specified physiological processes, given that most are biophilic and physiologically necessary to ensure the functioning of biota. The authors recall a notion from Paracelsus that: "Everything is poison, and nothing is devoid of poison; a single dose makes the poison invisible" (Hartman 2012). The current level of scientific advancement does not allow the physiological need for pollutants $(\mathrm{Hg}, \mathrm{Pb}, \mathrm{Cd})$ to be established, hence the a priori envisioning of these elements as of exceptional toxicology.

These circumstances make it advisable to pursue comprehensive research into a hydroecosystem as a complex multifunctional system characterized by the superpositioned interaction of a large number of factors in dynamic variations. Where mineralogical studies are concerned, different variations affecting (the composition and location of) heavy metals help shape the physicochemical characteristics of a hydroecosystem. The three key components of bottom sediments are sand (quartz-feldspar), clay and organic matter, which are present in different ratios, primarily in connection with flow rate as the determinant of the conditions for deposition (Andrusishyn \& Grubinko 2012; Smyrnov \& Smyrnova 2014; Voytyuk et al. 2014; Sukharev 2015; Klymenko et al. 2016; Mitryasova et al. 2018; Lyuta 2018).

Monographic study has focused on the components of the water balance in the basin of the Southern Bug, with levels of water mineralisation determined in the range $600 \mathrm{mg} / \mathrm{dm}^{3}$ (at the time of spring floods) up to $674 \mathrm{mg} / \mathrm{dm}^{3}$ (at the time of low water in summer and autumn) (Khilchevsky 2009.).

Noteworthy in the present context are fragmentary studies of pollution in the Bug estuary, downstream of the Southern Bug and which, from a geographical point of view, covers the distance from the Varvarivka district of Mykolaiv to the Black Sea water area, which grows to $2-3 \mathrm{~km}$ at a maximum depth in the lower reaches equal to 5-6 m (Mitryasova et al. 2017b). There is a GISoriented systemic approach to the generation of digital cartographic models of the heavy metal pollution that is adopted to achieve determinations in regard to the ecological and geochemical indicators of the state of the Bug estuary. Technogenic-anomalous zones with high contents of the heavy metals $\mathrm{Zn}, \mathrm{Ni}, \mathrm{Mn}, \mathrm{Pb}$ and $\mathrm{Cu}$ in bottom sediments are confined to the areas under the influence of industrial enterprises (Smyrnov \& Smyrnova 2014; Pohrebennyk et al. 2017).

Geochemical studies of migration peculiarities and sorption capacities relating to heavy metals should be considered in relation to the analytical dependence on the content of total organic carbon in bottom sediments. This approach helps explore the geochemical aspects of sedimentation. In the hydroecosystems prone to the anthropogenic impact, TOC in bottom sediments is one of the geochemical indicators serving to characterise the state of a river ecosystem (Osadchaya et al. 2003; Ignatieva et al. 2008).

Given the list of scientific research on the ecological and geochemical processes of bottomsediment formation in aqua landscapes, emphasis should be placed on determining the methodological basis for the correlation-regression dependence of the heavy metal accumulation processes in bottom sediments on total organic carbon 
content. Therefore, the aim of the presented work was determination of that kind of correlationregression dependence over a longer distance of Southern Bug hydroecosystems in the Nova Odesa-Mykolaiv area.

\section{MATERIALS AND METHODS}

The research method is based on strategic postulates of long-distance testing in line with the following principles:

- account is taken of the content of the Southern Bug hydroecosystem and the location of settlements as downstream sampling points are selected and as efforts are made to achieve maximum approximation of a regular grid after Ostrovsky \& Ostrovsky (1998);

- a bathometer and a bucket dredger of Mordukhai-Boltovsky design of capture area $1 / 40 \mathrm{~m}^{2}$, are used in sampling during the summer period (using a summer data slice), after RD 52.24.609-2013;

- there is compliance with the laboratory-testing methods for the samples from land involving temperatures above $40 \pm 5^{\circ} \mathrm{C}$, as well as $1 \mathrm{~mm}$ mesh sieving.

- determinations of the gross contents of the $\mathrm{K}$, $\mathrm{Ti}, \mathrm{Cr}, \mathrm{Fe}, \mathrm{Ni}, \mathrm{Cu}, \mathrm{Zn}, \mathrm{Rb}, \mathrm{Sr}$ and $\mathrm{Hg}$ metals in the samples are performed by way of extraction into an acid solution, in a ratio of solid and liquid phases of 1:5, and with heating and periodic stirring during the day. Leaching of samples is followed by filtering on a blue filter paper.

- The chemical elements in the samples are determined by X-ray spectrometry, with use made of an S2 PICOFOX Bruker X-ray spectrometer with silicon drift detector, a MNX 50P50/XCC high-voltage generator, and air-cooled metal MCB50.-0.7G as the source of X-rays and multilayer monochromator X-ray optics.

Prior to the analytical determinations of organic carbon, the samples were treated with concentrated $\mathrm{HCl}$ removing inorganic carbonates and bicarbonates in the form of $\mathrm{CO}_{2}$. Thermal oxidation with ozone was used as a method of TOC research, the sample being burnt in a reactor at around $1000^{\circ} \mathrm{C}$. Full oxidation of carbon components was achieved using copper oxide plus catalyst. The catalysis burning in the presence of a wide-range IK detector allows for the determination of TOC in a range up to $4000 \mathrm{mg} / \mathrm{dm}^{3}$. Further expansion of the measurement range is achieved by diluting samples with distilled water.

Statistical processing of the experimental data involved the Microsoft Excel and Statistics 10.0 packages. The heavy metal characterisation involved indicators as in Table 1, i.e. $\mathrm{C}_{\mathrm{i} \text { 'av }}$ - the values for heavy metals in the areas studied, $\mathrm{C}_{\mathrm{i}, \min }-$ the minimum concentration, $C_{i, \max }-$ the maximum concentration, $C_{i}$ - the metal content in the $i$-th sample of bottom sediments selected at point $n$.

Ukraine has no regulations regarding the content of heavy metals in bottom sediments. In consequence, assessments of the level of chemical pollution are made using the indicator $K_{c}$, in combined geochemical and geohygienic studies of the natural environment. $K_{c}$ is the ratio (in line with Formula 1) of the actual content of heavy metals in a soil $\left(C_{i}\right.$ in $\left.\mathrm{mg} / \mathrm{kg}\right)$ to the regional background content of $\left(C_{f}\right)$ :

$$
K_{C}=\frac{C_{i}}{C_{f i}}
$$

\section{RESULTS AND DISCUSSION}

The basin of the Southern Bug River is 1ocated mainly in the area of the Ukrainian Crystal Shield and only its lower course, along with the largest tributary - Ingul - is located in the area of the Black Sea Lowlands. In the upper part of the basin there are crystalline rocks close to the surface, with these reaching the surface in some parts of the river valley. Research was carried out at the bottom of the hydro Southern Bug - in the area between the towns of Mykolaiv and Nova Odesa (Fig. 1).

This site in the Mykolaiv area is subject to considerable technogenic loading. The main source of heavy metals in the river basin is the insufficiently-treated effluent from industrial enterprises, which contain significant amounts (tens or hundreds of milligrams per litre) of chemical elements. The processes by which heavy metals transform in the hydroecosystem of the Southern Bug partially determine the removal of heavy metals via transit in the current. Still, most are sorbed by suspended solids, before being deposited in the form of sorbed conglomerate and constituting stable geochemical anomalies over a timespan of decades. 


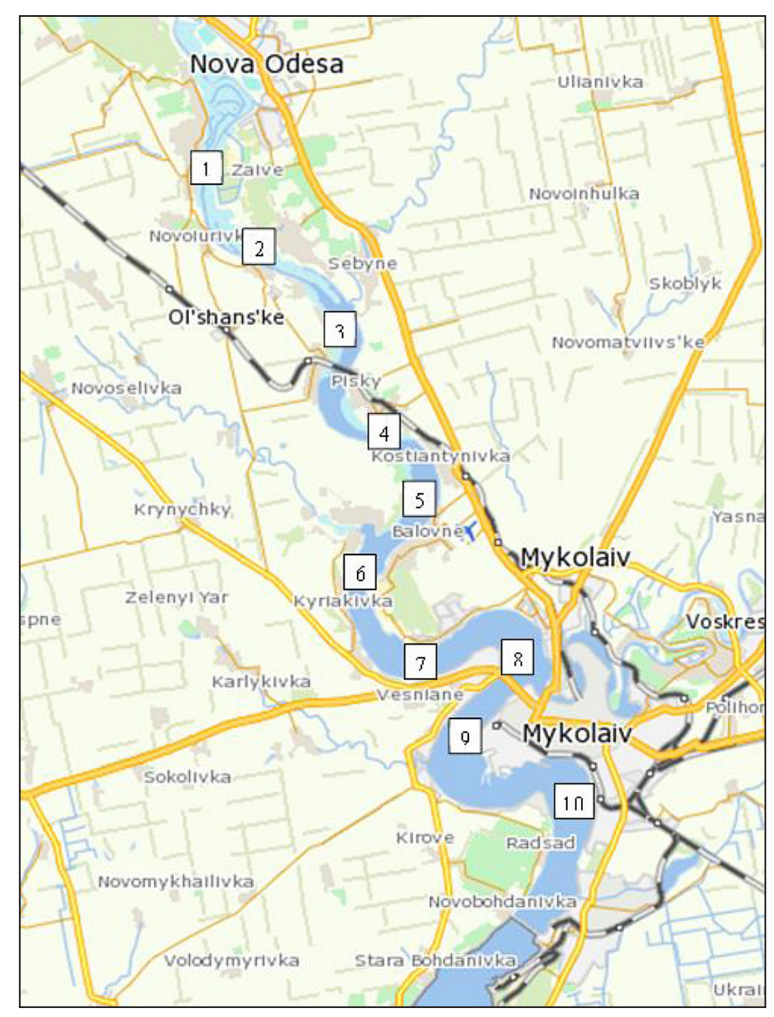

Figure 1. Points at which the bottom sediments of the Southern Bug River were sampled: 1 Kovalivka; 2 - Sapetnya; 3 - Trihati; 4 - Huriivka; 5 - Konstantinovka; 6 - Kyryakivka; 7 - Nadbuzke (Sources); 8 - Varvarivka; 9 - Mykolaiv Riverport; 10 - Mykolaiv Seaport.

Among the heavy metals, K, Ti, $\mathrm{Cr}, \mathrm{Fe}, \mathrm{Ni}$, $\mathrm{Cu}, \mathrm{Zn}, \mathrm{Rb}, \mathrm{Sr}$ and $\mathrm{Hg}$ have the greatest environmental relevance (Table 1). The choice of these elements reflects aspects of their impact on aquatic organisms, which respond to pollution of the hydroecosystem by way of various functional disorders, and manifestations of persistent chronic abnormalities in line with prolonged exposure to a given element. Indeed, even imbalances among trace elements or a change in ratios thereof in the bodies of aquatic organisms may lead to pathological physiological or functional conditions.

The specific contents of chemical elements in the samples varies across the 0.3 to $81 \%$ range. The figures for absolute contents of heavy metals in the bottom sediments are as follows: $\mathrm{K}(1374)>$ $\operatorname{Ti}(105.7)>\operatorname{Sr}(88.2)>\mathrm{Cr}(42.7)>\mathrm{Zn}(38.2)>\mathrm{Rb}$ (17.4) $>\mathrm{Fe}(10)>\mathrm{Cu}(9.8)>\mathrm{Ni}(9.5)>\mathrm{Hg}(5.9)$.

References to hazard classes demonstrate the level of danger posed to aquatic organisms by the chemical elements constituting the pollutants of the Southern Bug hydroecosystems. The indicator in question depends on the toxicity of heavy metals, the degree to which they accumulate in aquatic organisms, the degree to which the signs of harm are limited, and the capacity to cause adverse long-term effects.

The ability of aquatic organisms, both plants and animals, to deposit toxic substances reflects different levels of organisation complexity. In fish, heavy metals can be deposited in skin, bones, muscles and gills. In molluscs, toxicants accumulate in the mantle cavity, and some in muscles. In higher aquatic vegetation, the deposition of many poisons is observed in roots (Dudnik 2014).

The statistical analysis to determine the mechanism of redistribution and migration of heavy metals in the hydroecosystem of the Southern Bug involved the method of pairwise correlation and regression using the standard means of the Microsoft Excel analysis package. The authors sought to identify the main interacting parameters (the content of heavy metals in relation to the sorption capacity for TOC), both of which are covered by Directive provisions.

Total organic carbon (TOC) is among the most important parameters in that it reflects the content of all organic compounds (as an absolute magnitude). TOC in water can be bound chemically or be present in dissolved or suspended substances, including elemental carbon. TOC is able to form stable complexes with heavy metals, acting as an indicative factor in the development of a field of bottom-sediment pollution. In our opinion, the correlation-regression method used aimed at identifying the dependent relationships between heavy metals and TOC in bottom sediments. The method is a priority indicative indicator that can determine the extent of bottomsediment pollution.

\section{Elements in Danger Class I}

The data on the chromium toxicity seem contradictory, apparently in line with the valence of the element, the types of compounds it forms, and a number of other factors. The chromium toxicity varies with the degree of oxidation, the $\mathrm{Cr}(\mathrm{VI})$ compounds being 100-1000 times more toxic than those of $\mathrm{Cr}$ (III). The physiological need for $\mathrm{Cr}(\mathrm{III})$ is proven, being part of the glucose tolerance complex GTF; which regulates the glucose metabolism in living organisms (Drits 1985; Snitinsky et al. 1999; Vincent 2000).

The chromium content in the study area is presented as in the range $16.1-113.5 \mathrm{mg} / \mathrm{kg}$, with an average figure of 42.7 . From the village 
of Kovalivka to that of Nadbuzke (points 1-7) the levels of the element vary across the range $16.4-32.9 \mathrm{mg} / \mathrm{kg}$. In turn, the area from Varvarivka to the Seaport (points 8-10) is influenced by the Mykolaiv industrial and urban agglomeration, which causes an increase in the concentration of $\mathrm{Cr}$ in bottom sediments and the development of an anomaly. In this area, the content of $\mathrm{Cr}$ increases almost 5 -fold, and varies between $73.8-113.5 \mathrm{mg} / \mathrm{kg}$ (Table 1). A positive correlation of $\mathrm{Cr}$ with TOC is manifested (Fig. 2c), meaning that the Cr compounds correlate with TOC up to $58 \%$. The background regional zinc content is $40 \mathrm{mg} / \mathrm{kg}$ (Order of the Ministry of Emergency Situations of Ukraine 2012). Arithmetically averaged zinc content in the area v. Kovalivka-Seaport is defined at the level of $38.2 \mathrm{mg} / \mathrm{kg}$, with variation in the range $22.2-47.3 \mathrm{mg} / \mathrm{kg}$. An abnormally elevated content of $\mathrm{Zn}$ is only observed near Varvarivka, where the influence of the Mykolaiv industrialurban agglomeration is visible. This part of the Southern Bug determines an abnormal increase in the $\mathrm{Zn}$ content up to 2 times relative to the background, and is $72.5 \mathrm{mg} / \mathrm{kg}$ (Table 1). There is a positive correlation between $\mathrm{Zn}$ and TOC.
Zn compounds correlate with TOC up to $51 \%$ (Fig. 2g).

In the Earth's crust, mercury appears mainly in a diffuse state, at an average mass content of $8.3 \cdot 10^{-6} \%$. Being present in its elemental state, mercury creates inorganic and organic compounds. Out of the organometallic compounds, the most toxic are those of alkylmercury, in which the bond between mercury and carbon is stable, i.e. not destroyed in the presence of water, acids or alkalis. Mercury that enters water usually accumulates in its bottom sediments, with any further migration associated with incorporation into the trophic chain. This operates via planktonic organisms - crustaceans - fish - birds, for example (Krainyukov \& Timchenko 2016), and the possibility for a human being to also be included is clear.

Thus, some $\mathrm{Hg}$ in the environment derives from natural sources, influenced by anthropogenic impacts. In the latter case, the main sources are the emissions into the atmosphere as various fuels are combusted, as well as discharges of wastewater from industrial enterprises, technological processes using mercury and its compounds; and surface runoff from agricultural land on which

Table 1. A statistical characterisation of bottom sediments of the Southern Bug by reference to the contents of heavy metals

\begin{tabular}{|c|c|c|c|c|c|c|}
\hline Element & $\begin{array}{l}\text { Atomic } \\
\text { number }\end{array}$ & $\begin{array}{l}\text { Atomic } \\
\text { mass }\end{array}$ & $\begin{array}{c}\text { Absolute content in } \\
\text { bottom sediments, } \\
(\mathrm{mg} / \mathrm{kg})\end{array}$ & $\begin{array}{c}\text { Specific } \\
\text { content in bottom- } \\
\text { sediment samples }(\%)\end{array}$ & $\begin{array}{l}\text { Class of } \\
\text { danger }^{1}\end{array}$ & $\begin{array}{c}\text { Background, } \\
\text { mg/kg } \\
\text { (Lyuta 2018) } \\
\end{array}$ \\
\hline K & 19 & 39.10 & $\begin{array}{c}89.1-2882 \\
1374\end{array}$ & 80.8 & III & - \\
\hline $\mathrm{Ti}$ & 22 & 47.88 & $\begin{array}{c}11.9-260 \\
105.7\end{array}$ & 6.2 & III & - \\
\hline $\mathrm{Cr}$ & 24 & 51.10 & $\begin{array}{c}16.1-113.5 \\
42.7\end{array}$ & 2,5 & I & 40 \\
\hline $\mathrm{Fe}$ & 26 & 55.85 & $\begin{array}{c}6.9-15.1^{*} \\
10.0\end{array}$ & 0.6 & III & - \\
\hline $\mathrm{Ni}$ & 28 & 58.69 & $\begin{array}{c}7.3-12.7 \\
9.5\end{array}$ & 0.6 & II & 20 \\
\hline $\mathrm{Cu}$ & 29 & 63.55 & $\begin{array}{c}6.6-15.3 \\
9.8\end{array}$ & 0.6 & II & 28 \\
\hline $\mathrm{Zn}$ & 30 & 65.39 & $\begin{array}{c}22.2-72.5 \\
38.2\end{array}$ & 2.2 & I & 40 \\
\hline $\mathrm{Rb}$ & 37 & 85.47 & $\begin{array}{c}0.3-26.7 \\
17.4\end{array}$ & 1.0 & II & - \\
\hline $\mathrm{Sr}$ & 38 & 87.62 & $\begin{array}{c}20.9-296.4 \\
88.2\end{array}$ & 5.2 & III & 400 \\
\hline $\mathrm{Hg}$ & 80 & 200.59 & $\begin{array}{c}0.1-10.8 \\
5.9\end{array}$ & 0.3 & I & - \\
\hline
\end{tabular}

Notes: * The content of the element is given in $\mathrm{g} / \mathrm{kg}$; in the numerator - limit definitions: $\mathrm{C}_{\mathrm{i}, \min }-$ the minimum concentration of heavy metals, $\mathrm{C}_{\mathrm{i} \text {,max }}$ - the maximum concentration of HM, in the denominator $-\mathrm{C}_{\mathrm{i}, \text { total }}-$ the average value for the heavy metal at the points studied.

${ }^{1}$ Order of the Ministry of Emergency Situations of Ukraine "On approval of the Requirements to employers for the protection of workers from the harmful effects of chemicals" from 22.03.2012 №. 627. Access: https://zakon.rada.gov.ua/laws/show/z0521 (in Ukrainian) 
a)

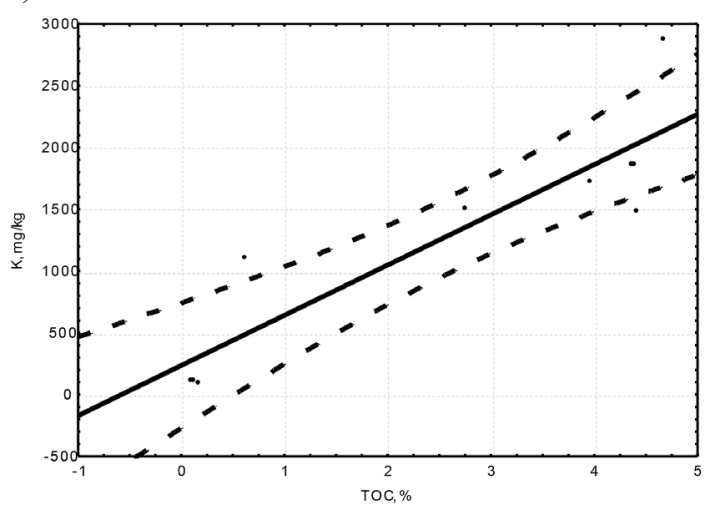

c)

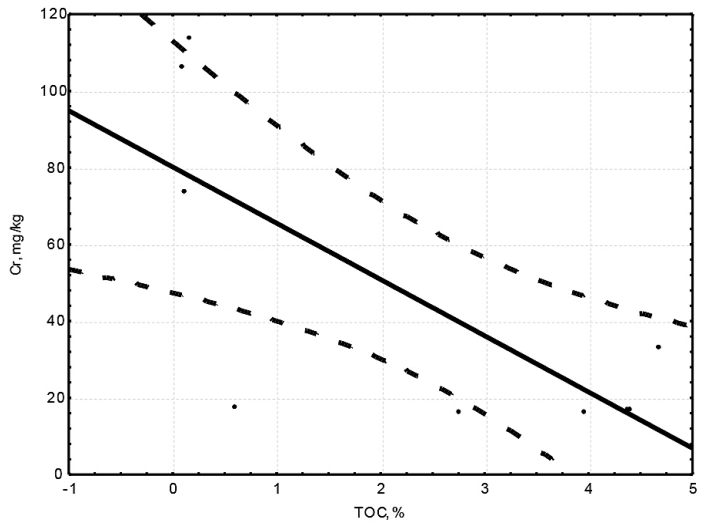

e)

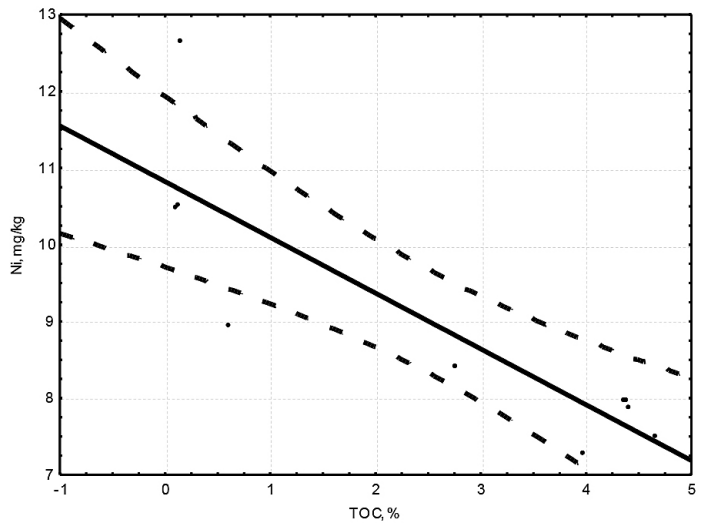

g)

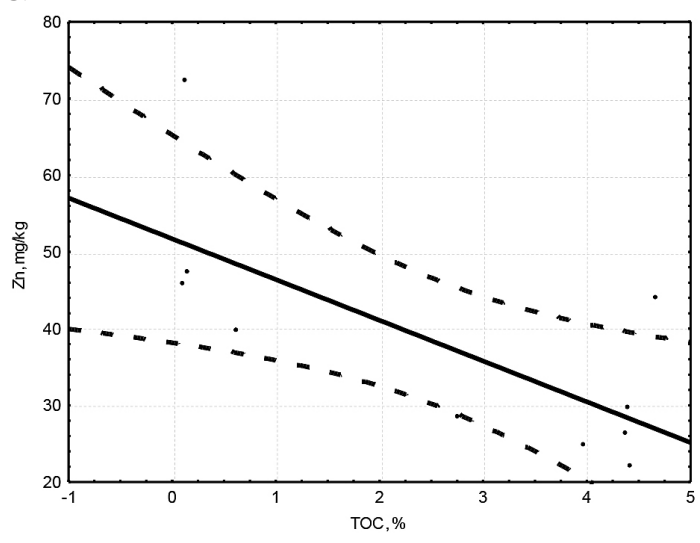

b)

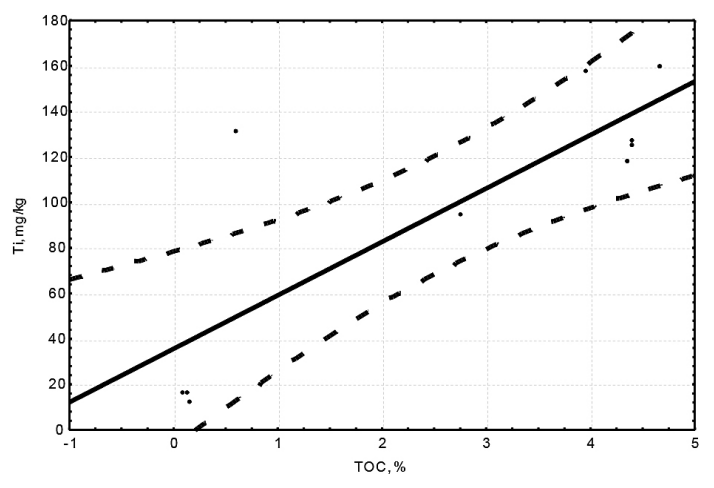

d)

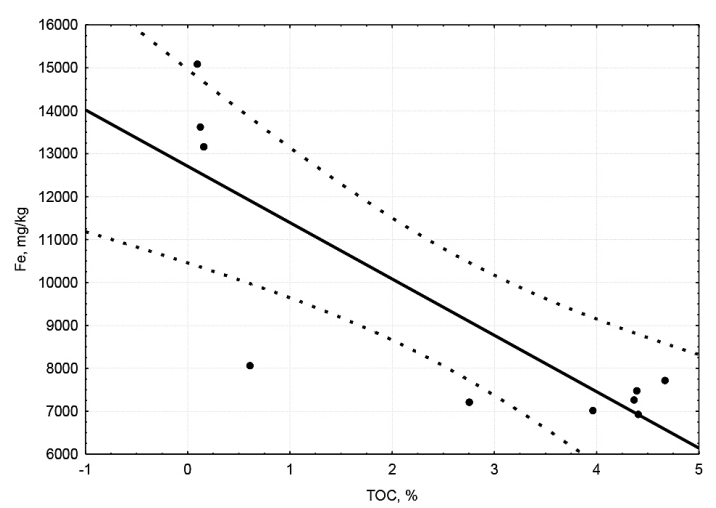

f)

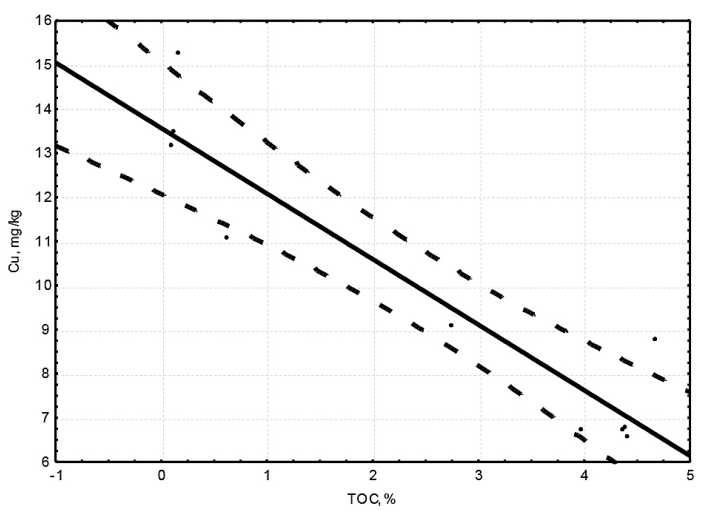

h)

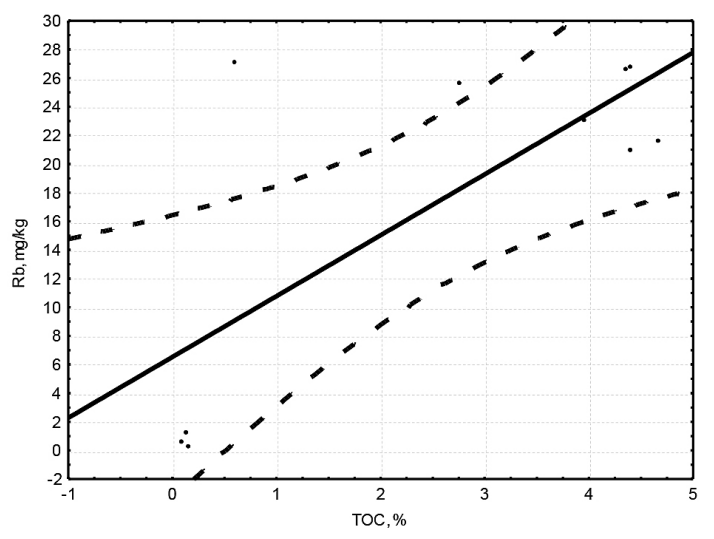


i)

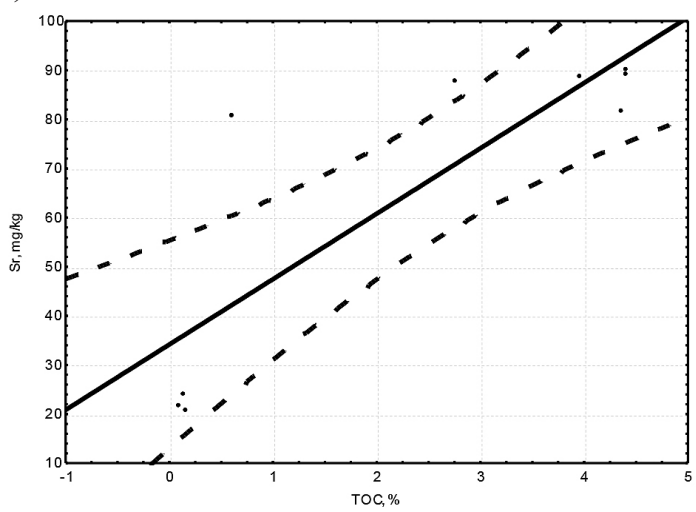

j)

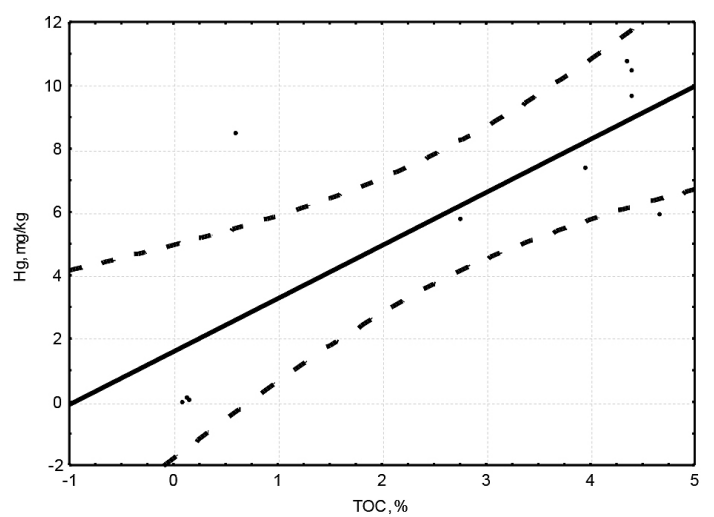

Figure 2. Regression relationship between TOC content and heavy metals in the bottom sediments of the Southern Bug hydroecosystem

Notes: Sampling points are marked in Figure 1.

the biocides containing mercury compounds have been applied.

The contents of mercury along the stretch of river studied range from 0.1 to $10.8 \mathrm{mg} / \mathrm{kg}$, with the weighted average figure being $5.9 \mathrm{mg} / \mathrm{kg}$. The highest content characterised the Gurivka-Konstantinovka area (points 4-5), with up to $11 \mathrm{mg} / \mathrm{kg}$. However, in the area of Varvarivka Seaport, the content is a steady $0.1 \mathrm{mg} / \mathrm{kg}$, given that natural dilution has taken place. There is a positive correlative link between $\mathrm{Hg}$ and TOC that reaches 63\% (Fig. 2j).

\section{Elements in Danger Class II}

The average concentration of $\mathrm{Ni}$ in bottom sediments is $9.5 \mathrm{mg} / \mathrm{kg}$, or only half as much as the regional background of $20 \mathrm{mg} / \mathrm{kg}$. However, the concentrations of nickel across the study area range from 7.3 to $12.7 \mathrm{mg} / \mathrm{kg}$ (Table 1). A higher Ni content of up to $12 \mathrm{mg} / \mathrm{kg}$ is observed in the area of operation of the Mykolaiv industrial and urban agglomeration, namely near Varvarivka River and Seaport (points 8-10). In turn, the aforementioned value of 12.5 relates to the separate location of Kovalivka, which is downstream of Nova Odesa (Table 1).

Excessive concentrations of $\mathrm{Ni}$ compounds have toxic impacts on aquatic organisms. The determined $\mathrm{LC}_{50}$ and $\mathrm{LC}_{100}$ values relate to the deaths of mirror carp (Cyprinus carpio) $200 \mathrm{~h}$ after the exposure to nickel chloride at concentrations of $4.5-10.0 \mathrm{mg} / \mathrm{dm}^{3}$. The same indicators apply to rainbow trout (Parasalmo penshinensis) with $25.0 \mathrm{mg} / \mathrm{dm}^{3}$, and to golden tench (Tinca tinca) at a concentration of $55.0 \mathrm{mg} / \mathrm{dm}^{3}$. Daphnia pulex is the aquatic organism found to be most sensitive to the toxic effects of nickel (at $1.9 \mathrm{mg} / \mathrm{dm}^{3}$ ) (Zelikoff 1998; Zelikoff et al. 2002). Pinkina, in turn, considers the processes by which molluscs adapt to excessive concentrations of $\mathrm{Ni}^{2+}$ under systemic exposure, which cause depressive states due to impaired adaptive mechanisms.

A positive correlation of $\mathrm{Ni}$ with $\mathrm{TOC}$ is to be noted, with values of up to $75 \%$ (Fig. 2e).

The concentrations of copper in the study area range from 6.6 to $15.3 \mathrm{mg} / \mathrm{kg}$, with the weighted average being $9.8 \mathrm{mg} / \mathrm{kg}$. In the Trykhaty-Kostiantynivka area (points 3-5), the determined concentrations were of $6.6-6.8 \mathrm{mg} / \mathrm{kg}$. The $\mathrm{Cu}$ content is up to twice as high in the Kyryakivka and Mykolaiv Riverport area (points 6-9) - in the range 9.1-15.3 (Table 2). Cu correlates positively with TOC, with values up to $87 \%$ (Fig. 2f).

It is known that algae of different systematic groups react differently to the same doses of copper. Green algae (Chlorophyta) are seen to be characterised by a relatively high level of resistance (Dudnik 2014). Likewise, due to the thickening and multiplicative fragmentation of cell membranes in Lemna minor, this species of duckweed is also adapted to the action of stress factors via the protective-compensatory adaptation of cells (Kostyuk \& Grubinko 2011).

Living organisms have no specific need for rubidium either, or at least such a need has not been identified yet. Cells absorb the ions of this element in a manner similar to that noted for the sodium ions. Rubidium proves to be somewhat radioactive, due to the significant content of the weakly radioactive isotope ${ }^{87} \mathrm{Rb}$ (Butterman \& Reese 2003). 
In the studied area, rubidium is present at concentrations in the $0.3-26.7 \mathrm{mg} / \mathrm{kg}$ range, with the weighted average being $17.4 \mathrm{mg} / \mathrm{kg}$. There is a clearly elevated content in areas between Kovalivka and Nadbuzke (points 1-7), which report values in the $21-27 \mathrm{~g} / \mathrm{kg}$ range. At the sites influenced by the Mykolaiv industrial and city agglomeration - from Varvarivka (point 8) to Mykolaiv Seaport (point 10) - the content of $\mathrm{Rb}$ is $0.3-1.3$, or only one-twentieth as much (points 1-7) (Table 1). Rb correlates positively with TOC up to a level of $56 \%$ (Fig. 2h).

\section{Elements in Danger Class III}

Potassium (K) is one of the commonest petrogenic elements in the Earth's crust, present at a level of $2.5 \%$ by weight. Due to its high level of chemical activity, the element does not occur in its free state in nature, but only in such minerals as sylvin $\mathrm{KCl}$, sylvinite $\mathrm{KCl} \cdot \mathrm{NaCl}$, carnallite $\mathrm{KCl} \cdot \mathrm{MgCl}_{2} \cdot 6 \mathrm{H}_{2} \mathrm{O}$ and kainite $\mathrm{KCl} \cdot \mathrm{MgSO}_{4} \cdot 3 \mathrm{H}_{2} \mathrm{O}$ (Drits 1985).

The potassium contents noted in the study area are of $89.1-2882 \mathrm{mg} / \mathrm{kg}$, though the average value is 1374. From Kovalevka to Varvarivka (points 1-9) there are successively lower values for concentrations of the element - across the range 2882 to $108.7 \mathrm{mg} / \mathrm{kg}$ (Table 1). The main compounds that pollute the Southern Bug include: $\mathrm{KCl}, \mathrm{KNO}_{3}, \mathrm{~K}_{2} \mathrm{SO}_{4}, \mathrm{~K}_{2} \mathrm{CO}_{3}$ and $\mathrm{K}_{2} \mathrm{Cr}_{2} \mathrm{O}_{7}$. Natural flow in turn reflects the presence of the minerals sylvin $\mathrm{KCl}$, vinite $\mathrm{KCl} \cdot \mathrm{NaCl}$, carnallite $\mathrm{KCl} \cdot \mathrm{MgCl}_{2} \cdot 6 \mathrm{H}_{2} \mathrm{O}$ and kainite $\mathrm{KCl} \cdot \mathrm{MgSO}_{4} \cdot 3 \mathrm{H}_{2} \mathrm{O} . \mathrm{K}$ correlates positively with TOC (Fig. 2a), up to a level of $82 \%$.

While the average content of titanium in the Earth's crust is $0.45 \%$, the element can be present in aqueous solutions in the form of purple Ti(III) cations and colourless Ti(IV). The Ti(III) compounds act as strong reducing agents, and are thus unstable in solution as they oxidised by air rapidly to Ti(IV). Equally, the latter is only able to persist in a strongly acidic environment. The salts of titanium (IV) in aqueous solution hydrolyse readily in the form of the colourless tytanil ion $\mathrm{TiO}^{2+}$ (Drits 1985).

The titanium contents in the study area are of $11.9-260 \mathrm{mg} / \mathrm{kg}$, with an average value of 105.7 . From the village of Kovalevka down to Kyryakivka (at points 1-6) there is a decrease in the concentration of the element across the range 260-94.8 mg/kg (a 2.5-fold difference). Between
Kyryakivka and Mykolaiv Seaport (at points 6-10), concentrations of Ti in bottom sediments show an almost 6-fold decline (Table 1).

About 100 titanium minerals are known, among which ilmenite is widespread (43.7-52.8\% $\mathrm{TiO}_{2}$ ). Then there is rutile, anatase and brookite $\left(94.2-99.5 \% \mathrm{TiO}_{2}\right)$; leucoxene (61.9-97.6\% $\mathrm{TiO}_{2}$ ); loparite $\left(38.3-41 \% \mathrm{TiO}_{2}\right)$; sphen (33.7$40.8 \%$ ) and perovskite $\left(38.7-57.8 \% \mathrm{TiO}_{2}\right)$. The amount of titanium in the Earth's crust is several times greater than the reserves of copper, zinc, lead, gold, silver, platinum, chromium, tungsten and mercury. Our results show a positive correlation between Ti and TOC (Fig. 2b), up to the level of $67 \%$.

Iron is the fourth most common element in the Earth's crust after O, Si, and A1 (Drits 1985). It forms about 300 minerals, most of which are compounds also containing oxygen. Silicates predominate, and among them a large proportion are amphiboles, pyroxenes and mica. Assessments of the geochemical activity of this element are rather ambiguous. First, although this chemical element has been recognised as prevalent in the natural environment, there are still no proposed standards for its content in soils. Secondly, it is a biophilic element and is among the main physiologically necessary trace elements. Given the specific features of iron, our assessment of it is reduced to a description of variations in level present in the hydroecosystem of the Southern Bug.

Thus, within the area under study, $\mathrm{Fe}$ is present at concentrations in the $7.0-15.0 \mathrm{~g} / \mathrm{kg}$ range, with the weighted average figure being $10 \mathrm{~g} / \mathrm{kg}$. There is a clear dependent relationship between elevated contents and the locations of Nova Odesa (point 1) and Mykolaiv (points 8-10). There, the concentrations are of 13.7 and $13.2-15.1 \mathrm{~g} / \mathrm{kg}$, respectively. The highest iron concentration of all is that characterising Mykolaiv Seaport, adjacent to which we find the PJSC "Black Sea Shipyard", which has been in operation for more than 100 years now (Table 2 ). Fe correlates positively with TOC to a level of up to $70 \%$ (Fig. 2d).

The average mass content of strontium in the Earth's crust is $3.4 \cdot 10^{-2} \%$. It represents an impurity in the crystalline mineral hradkah, along with calcium, potassium and barium; as well as forming the insoluble strontium hydroxide $\operatorname{Sr}(\mathrm{OH})_{2}$ (Drits 1985).

The high concentration of $\mathrm{Sr}$ recorded near Nova Odesa was of $300 \mathrm{mg} / \mathrm{kg}$ (point 1) (Fig. 2i). This level is 5 times the average (of $65 \mathrm{mg} / \mathrm{kg}$ ) 
noted for the rest of the study area. Natural $\mathrm{Sr}$ may be leached from calcium minerals that come to the surface near the faults of the Ukrainian Shield, and the element may indeed be present across the concentration range $20.9-300 \mathrm{mg} / \mathrm{kg}$. Given the major differences in the Sr content, we arrived at a weighted average value of $88.2 \mathrm{mg} / \mathrm{kg}$ in the bottom sediments under study.

The spatial distribution of strontium within the Southern Bug hydroecosystem shows that the levels of this element decline from 300 to just $22 \mathrm{mg} / \mathrm{kg}$ at Mykolaiv Seaport (point 10). This distribution of $\mathrm{Sr}$ in bottom sediments around the area is affected by the processes of erosion involving calcium minerals - with concentrations lower at greater distances from the source. There is also a process of adsorption from water involving plants like yellow waterlily (Nuphar luteum) and reed (Phragmites australis). The processes of accumulation of ${ }^{137} \mathrm{Cs}$ and ${ }^{90} \mathrm{Sr}$ by such higher aquatic plants and by the phytoepiphyton in reservoirs in urban areas are thus considered in the 2007 publication by Klochenko and co-authors. The Cs isotopes are not thought to play a significant biological role, and even excess fluctuations of natural origin can pose a risk to aquatic organisms. Our finding is that $\mathrm{Sr}$ correlates positively with TOC, at a level of up to $73 \%$ (Fig. 2i).

As it has been noted, the toxicity of heavy metals to aquatic organisms depends on the forms in which they are present in the aquatic environment. Depending on the conditions manifested in that environment, heavy metals can be oxidised to differing degrees, forming part of various inorganic and organometallic compounds which can be truly soluble, distributed colloidally or form part of mineral and organic suspensions. Some metals can combine with organic compounds to form quite strong complexes -being among the most important forms by which migration through natural waters take place. This reflects the stability of the complexes concerned. In an aqueous medium, the toxicity of metals can change as they transit to metal-complex forms. This ensures that the processes of sedimentation are decisive in shaping the field of bottom-sediment pollution.

The sedimentation capacity of the heavy metals studied has been determined using the aforementioned procedure of ranking pairwise correlation coefficients (Table 2).

The ranking of TOC:HM in declining order is thus: TOC: $\mathrm{Cu}(0.87)>$ TOC:K $(0.82)>$ TOC:Ni $(0.75)>$ TOC: $\mathrm{Sr}(0.73)>\mathrm{TOC}: \mathrm{Fe}(0.7)>$ TOC:Ti $(0.67)>$ TOC:Hg $(0.63)>$ TOC:Cr $(0.58)>$ TOC: $\mathrm{Rb}(0.56)>$ TOC: $\mathrm{Zn}(0.51)$.

Such calculation of correlation coefficients is a matter of practical necessity, as - for example the phenomenon of the affinity of heavy metals for TOC must be studied, given formation under the influence of not one, but many different factors, some of which may not have a decisive influence on their own. The cumulative influence of factors is sometimes strong enough to ensure reference to the changes they undergo as conclusions are drawn in regard to the values for the phenomenon under study.

\section{CONCLUSIONS}

The most dangerous kind of anthropogenic loading on the hydroecosystem of the Southern Bug river is the pollution with environmentallyhazardous chemicals that are able to impair the self-purification and bioproduction processes and thus give rise to profound changes in the structural

Table 2. Ranking of pairwise correlation coefficients $\left(\mathrm{r}^{2}\right)$

\begin{tabular}{|l|c|c|c|c|c|}
\hline \multirow{2}{*}{ Parameter } & Specification & \multicolumn{4}{c|}{ Positive correlation } \\
\cline { 2 - 6 } & & $0.5-0.65$ & $0.65-0.75$ & $0.75-0.85$ & $0.85-1$ \\
\hline TOC: $\mathrm{K}$ & & - & 0.82 & - & - \\
\hline TOC: $\mathrm{Ti}$ & & - & 0.67 & - & - \\
\hline TOC: $\mathrm{Cr}$ & & 0.58 & - & - & - \\
\hline TOC: $\mathrm{Fe}$ & & - & 0.7 & - & - \\
\hline TOC: $\mathrm{Ni}$ & & - & 0.75 & - & - \\
\hline TOC: $\mathrm{Cu}$ & & - & - & - & - \\
\hline TOC: $\mathrm{Zn}$ & & 0.51 & - & - & - \\
\hline TOC: $\mathrm{Rb}$ & & 0.56 & - & - & - \\
\hline TOC: $\mathrm{Sr}$. & & - & 0.73 & - & - \\
\hline TOC: $\mathrm{Hg}$ & & 0.63 & - & - & $10 \%$ \\
\hline Specific weight, $\%$ & & $40 \%$ & $50 \%$ & - & - \\
\hline
\end{tabular}


and functional organisation of the aquatic ecosystem's biotic component.

The processes of inflow of heavy metals of technogenic origin from urban landscapes (of Nova Odesa and Mykolayiv) into the hydroecosystem of the Southern Bug are continuing actively, with further accumulation in bottom sediments taking place. Other processes giving rise to the secondary contamination of layers of water with heavy metals are able to shape the stable concentrations of pollutants there, influencing the processes of absorption through the body surface in aquatic organisms. In most cases, heavy metals exert their biological impact by affecting the enzymes that activate the metabolic processes. The danger of physiological processes in aquatic organisms causing disruption is what helps devise effective solutions.

The proposed methodological approach based on the correlation-regression dependence allows taking into account the relationship between levels of accumulation of heavy metals and the content of total organic carbon in the bottom sediments of rivers. The methodology in question enables to determine the geochemical aspects of the processes of sedimentation of chemical elements, along with general trends characterising the hydroecosystems prone to the anthropogenic impact. This reflects the way in which TOC in bottom sediments is a geochemical indicator of the state a river ecosystem finds itself in. A further advantage of the approach is the way it minimises the financial costs arising out of the analyses of chemical elements in bottom sediments, given that analytical dependence can be relied upon to a certain degree. The ranking of pairwise correlation coefficients allows for a representation of the affinities of different heavy metals with total organic carbon in descending order as follows: TOC: $\mathrm{Cu}(0.87)>$ TOC:K $(0.82)>$ TOC:Ni $(0.75)$ $>$ TOC:Sr 73) > TOC:Fe (0.7) > TOC:Ti (0.67) $>$ TOC:Hg (0.63) > TOC:Cr (0.58) > TOC: $\mathrm{Rb}$ $(0.56)>$ TOC: $Z n(0.51)$.

\section{REFERENCES}

1. Andrusishyn G., Grubinko V. 2012. Seasonal Dynamics of Metal Content in Water and Bottom Sediments of the River Zbruch. Bulletin of the Lviv University. The series is biological, 58, 165-174 (in Ukrainian). Access: http://prima.lnu.edu.ua/faculty/ biologh/wis/58/3/18/18.pdf
2. Bartoszek, L., Miąsik, M., Koszelnik, P. 2020. Trophic degradation predispositions and intensity in a high-flow, silted reservoir. PeerJ, 8, e9374.

3. Bezsonov Ye., Mitryasova O., Smyrnov V., Smyrnova S. 2017. Influence of the South-Ukraine electric power producing complex on the ecological condition of the Southern Bug River. Eastern-European Journal of Enterprise Technologies, 4/10 (88), 20-28.

4. Butterman W.C. \& Reese R.G. 2003. Mineral Commodity Profiles Rubidium, 11 p., Access: https:// pubs.usgs.gov/of/2003/of03-045/of03-045.pdf

5. Drits M. 1985. Properties of Elements. M.: Metallurgy, 672 p. (in Russian). Access: http: //www.vixri. ru/d2/Drica\%20M.E._SVOJSTVA\%20ELEMENTOV (spravochnik).pdf

6. Czarnota J., Masłoń A. 2019. valuation of the Effectiveness of a Wastewater Treatment Plant with MBBR Technology. Rocznik Ochrona Środowiska, 21(2), 906-925.

7. Dudnik S. 2014. Aquatic toxicology: method. Manual, Part 1. General basics of water toxicology, National University of Life and Environmental Sciences of Ukraine, K.: Fitosotsiotsentr, 180 p. (in Ukrainian).

8. DSTU EN 1484. 2003. Water research. Guidelines for the Determination of Total and Dissolved Organic Carbon (EN 1484: 1997, IDT), Access: http://online.budstandart.com/en/catalog/ doc-page?id_doc $=73074$

9. Hartman F. 2012. Zhyzn Paratselsa y sushchnost eho uchenyia (The life of Paracelsus and the essence of his teachings), p. 102 (in Russian). Access: https://books. google.ru/books?id=UYO8AQAAQBAJ\&amp

10. Ignatieva O., Ovsyany E., Romanov A., et al. 2008. Carbonate System of Waters and the Content of Organic Carbon in the Bottom Sediments of Sevastopol Bay (Black Sea) According to Observations from 1998 to 2005, Marine Hydrophysical Journal, 2, 57-67.

11. Klymenko M., Zalesky I., Bedunkova O. 2016. Spatial Distribution of Qualitative Characteristics of Heavy Metals in the Bottom Sediments of the Ustya River. Bulletin of the National University of Water Management and Environmental Sciences. Agricultural sciences, 3, 71-81 (in Ukrainian). Access: http://nbuv.gov.ua/UJRN/Vnuvgp_sg_2016_3_7

12. Khilchevsky V. 2009. Water resources and quality of river waters of the Southern Bug basin, Electronic resource, K.: Nika-chentr, 184, (in Ukrainian). Access: file: /// D: / - =\% 203 / REP0000615\% 20 (1).PDF.

13. Klochenko P., Harchenko G., Klenus V., Kaglyan A., Shevchenko T. 2007. Accumulation of 137Cs and $90 \mathrm{Sr}$ by Higher Aquatic Plants and Phytoepiphyton in Reservoirs of Urbanized Territories. 
Hydrobiological Journal, 43(5), 51-63.

14. Kostyuk K., Grubinko V. 2011. Reaction of Cell Membranes of Roecilia Reticilata Peter Caviar to the Action of Zinc and Lead Ions. Modern problems of theoretical and practical ichthyology: IV International. ichthyological scientific-practical conf.: these, Odessa: Fenix, 139-141.

15. Krainyukov O., Timchenko V. 2016. Influence of Chemical Substances of Toxic Action on Representatives of the Biotic Component of Aquatic Ecosystems. Problems of environmental protection and ecological safety, 38, 111-120 (in Ukrainian). Access: http://nbuv.gov.ua/UJRN/Ponp_2016_38_13

16. Lyuta N. 2018. Features of the Heavy Metals Distribution in the Bottom Sediments of Rivers in Ukraine. Mineral resources of Ukraine, 1, 28-32 (in Ukrainian). Access: http://nbuv.gov.ua/UJRN/ Mru_2018_1_6.

17. Martsenyuk V., Petruk V., Kvaternyuk S., Pohrebennyk V., Petruk R., Klos-Witkowska A. 2016. Multispectral control of water bodies for biological diversity with the index of phytoplankton. 16th International Conference on Control, Automation and Systems, ICCAS, HICOGyeongju, South Korea, 988-993.

18. Miller J. D., Vonk J., Staddon C., \& Young S. L. 2020. Is household water insecurity a link between water governance and well-being? A multi-site analysis. Journal of Water, Sanitation and Hygiene for Development Journal of Water, Sanitation and Hygiene for Development, 10(2), 320-334.

19. Mitryasova O., Pohrebennyk V., Kochanek A., Sopilnyak I. 2016. Correlation Interaction between Electrical Conductivity and Nitrate Content in Natural Waters of Small Rivers, Conference Proceedings «16th International Multidisciplinary Scientific Geoconference SGEM 2016», (Vienna, Austria, 2 November - 5 November 2016), Book 3, Water Resources. Forest. Marine and Ocean Ecosystems, Vol. III, 357-365.

20. Mitryasova O., Pohrebennyk V., Kochanek A., Stepanova O. 2017a. Environmental Footprint Enterprise as Indicator of Balance it's Activity. Proceedings of the 17th International Multidisciplinary Scientific Geoconference SGEM 2017, Albena, Bulgaria, 29 June - 5 July 2017, 17(51), 371-378.

21. Mitryasova O., Pohrebennyk V. 2017b. Integrated Environmental Assessment of the Surface Waters Pollution: Regional Aspect. Proceedings of the 17th International Multidisciplinary Scientific GeoConference SGEM 2017, Vienna, Austria, 27 November - 29 November 2017, 33(17), 235-242.

22. Mitryasova O., Pohrebennyk V., Kardasz P. 2018. Hydrochemical Aspects of Surface Water Quality Assessment. Proceedings of the 18th International Multidisciplinary Scientific Geoconference SGEM
2018, Albena, Bulgaria. 30 June - 9 July 2018, 5(18), 513-520.

23. Mitryasova O. Koszelnik P., Gruca-Rokosz R., Smirnov V., Smirnova S., Bezsonov Ye, Zdeb M., Ziembowicz S. 2020. Features of Heavy Metals Accumulation in Bottom Sediments of the Southern Bug Hydroecosystem. Journal of Ecological Engineering, 21(3), 51-60.

24. Order of the Ministry of Emergency Situations of Ukraine "On approval of the Requirements to employers for the protection of workers from the harmful effects of chemicals" from 22.03.2012 No. 627 (in Ukrainian). Access: https://zakon.rada.gov.ua/ laws/show/z0521

25. Organization and monitoring of the content of pollutants in the bottom sediments of water bodies: RD 52.24.609-2013. 2013. Access: https://files.stroyinf.ru/Data2/1/4293773/4293773618.htm

26. Osadchaya T., Ovsyaniy E., Kemp R. et. all. 2003. Organic Carbon and Oil Hydrocarbons in Bottom Sediments of Sevastopol Bay (the Black Sea). Mar. Ecol. J., II(2), 94-101.

27. Ostrovsky V., Ostrovsky L., 1998. A Methodical Recommendations for Compiling Geological and Ecological Maps at a Scale of 1: 200000 - 1: 100000, M.; VSEGINGEO, 36 p.

28. Raneesh KY. 2014. Impact of Climate Change on Water Resources, Journal of Earth Science \& Climatic Change, 1 5(3), 185. Access: https:/www. omicsonline.org/open-access/impact-of-climatechange-on-water-resources-2157-7617.1000185. php?aid $=25328$

29. Petruk R., Pohrebennyk V., Kvaternyuk S., Bondarchuk O., Cygnar M. 2016. Multispectral television monitoring of contamination of water objects by using macrophyte-based bioindication. 16th International Multidisciplinary Scientific GeoConference: Ecology, Economics, Education and Legislation, SGEM, Albena, Bulgaria, 2, 597-602.

30. Pinkina T. 2006. Influence of heavy metal ions of the aquatic environment on the growth, reproduction and development of the lake pond (Mollusca, Pulmonata): author's ref. dis. for science. degree of Cand. biol. Science: special. 03.00.17 "Hydrobiology", p. 23.

31. Pohrebennyk V. Mitryasova O., Klos-Witkowska A., Dzhumelia E., 2017. The Role of Monitoring the Territory of Industrial Mining and Chemical Complexes at the Stage of Liquidation, Proceedings of the 17th International Multidisciplinary Scientific GeoConference SGEM 2017, Vienna, Austria, 27 November - 29 November 2017. 33(17), 383-390.

32. Pohrebennyk V., Koshelnik P., Mitryasova O., Dzhumelia E., Zdeb M. 2019. Environmental Monitoring of Soils of Post Industrial Mining Areas. Journal of Ecological Engineering, 20(9), 53-61. 
33. Smyrnov V., Smyrnova S. 2014. Spatial Interpolation of Pollution of Bottom Sediments of the Bug estuary by Heavy Metals, Scientific Bulletin of Sukhomlynsky Mykolaiv University, Series: Biological Sciences, 63, 97-102 (in Ukrainian). Access: http:// nbuv.gov.ua/UJRN/nvmduc

34. Snitinsky V., Sologub L., Antonyak G. etc. 1999. The Biological Role of Chromium in Humans and Animals. Ukrainian Biochemistry Journal, 71(2), 5-10.

35. Styskal O., Ishchenko V., Petruk, R., Pohrebennyk V., Kochanek A. 2016. Assessment of chlorinated water impact on phytoplankton. 16th International Multidisciplinary Scientific Geoconference, SGEM, Vienna, Austria, 373-380.

36. Sukharev S. 2015. Determination of Some Heavy Metals in the Bottom Sediments of the Borzhava River by Atomic Absorption Spectroscopy. Scientific Bulletin of Uzhgorod University. Series: Chemistry, 1, 45-49 (in Ukrainian). Access: http://nbuv. gov.ua/UJRN/Nvuuchem
37. Vincent J. 2000. The Biochemistry of Chromium. J. Nutr., 130(4), 715-718.

38. Voytyuk Yu., Kuraeva I., Kroik G., Karmazynenko S., Matsibora O. 2014. Content and Forms of Finding Heavy Metals in Bottom Sediments in the Zone of Influence of Industrial Sources of Pollution, Gnoecology, 15, 1-7 (in Ukrainian). Access: https:// cyberleninka.ru/article/n/vmist-ta-formi-znahodzhennya-vazhkih-metaliv-u-donnih-vidkladahv-zoni-vplivu-promislovih-dzherel-zabrudnennya/ viewer

39. Zelikoff J. 1998. Biomarkers of immunotoxicity in fish and other non-mammalian sentinel species: predictive value for mammals. Toxicology, 129(1), 63-71.

40. Zelikoff J., Carlson E., Li Y., Raymond A., et al. 2002. Immunotoxicity biomarkers in fish: development, validation and application for field studies and risk assessment. Human and Ecological Risk Assessment, 8(2), 253-263. 